\title{
Urgensi Tumbuh Kembang Anak terhadap Pembentukan Karakter
}

\author{
Aas Siti Sholichah \\ Fakultas Tarbiyah Institut PTIQ Jakarta, Indonesia \\ shalichah@gmail.com
}

\begin{abstract}
Abstrak:
Fase perkembangan usia anak mempengaruhi pembentukan karakter. Usia 0-4 tahun perkembangan kognitif mencapai 50\%, usia ini disebut masa golden age. Usia 4-8 tahun sebesar 30\% dan usia 9-17 tahun 20\%. Apa yang dilihat, didengar dan dipelajari akan mengakar dan membentuk persepsi anak tentang kehidupan yang dialami. Jika anak pada usia ini dibesarkan dengan kasih sayang, penghargaan dan empati, maka apa yang dialami tersebut akan terukir dan mengakar menjadi karakter. Akan tetapi jika apa yang dilihat, dialami dan dirasakan sesuatu yang menyakitkan dan tidak aman, maka akan membentuk karakter yang mudah putus asa, labil dan keras kepala. Untuk itu peran orang terdekat yaitu orang tua memberikan andil dalam pembentukan karakter anak.
\end{abstract}

Kata Kunci: Anak, Fase Perkembangan, Pembentukan Karakter.

\begin{abstract}
:
The phase of development of the child's age affects the formation of character. Age 0-4 years cognitive development reaches $50 \%$, this age is called the golden age. Ages $4-8$ years by $30 \%$ and ages 9-17 years 20\%. What is seen, heard and learned will take root and shape the child's perception of life experienced. If a child of this age is raised with love, appreciation and empathy, then what is experienced will be engraved and rooted into character. But if what is seen, experienced and felt something painful and unsafe, it will form a character who is easily discouraged, unstable and stubborn. For that the role of the closest person, namely parents, contributes to shaping the character of the child
\end{abstract}

Keywords: Children, Development Phase, Character Building 


\section{Pendahuluan}

Anak adalah anugerah dari Allah Swt. untuk orang tua. Kehadiran anak merupakan dambaan bagi keluarga. Untuk memilikinya, berbagai upaya dilakukan. Dalam membesarkan anak, orang tua berupaya dengan sepenuh hati dan tenaga memberikan yang terbaik. Mencukupi kebutuhan pokok berupa sandang, pangan dan papan. Memberikan pendidikan (sekolah) yang terbaik, memfasilitasi anak dengan berbagai fasilitas untuk memberikan kenyamanan, bahkan untuk memenuhi dan memberikan yang terbaik, orang tua (ayah dan ibu) keduanya rela bekerja, menghabiskan masa produktifnya agar dapat hidup layak dan menjadikan anak-anak hidup sejahtera dan kelak merasakan kebahagiaan dan kesuksesan melebihi orang tua.

Berdasarkan hasil penelitian di bidang neurologi yang dilakukan oleh Benyamin S. Bloom, seorang ahli pendidikan dari Universitas Chicago, Amerika Serikat mengemukakan bahwa pertumbuhan sel jaringan otak pada anak usia 0-4 tahun mencapai 50\%, hingga usia 8 tahun mencapai $80 \% .{ }^{1}$ Pesatnya perkembangan otak tersebut bersamaan dengan pertumbuhan fisik anak. Untuk itu orang tua harus memberikan stimulasi agar anak dapat tumbuh dan berkembang dengan optimal.

Untuk dapat memaksimalkan usaha orang tua dalam membentuk karakter anak, maka orang tua harus berupaya menggali pengetahuan mengenai tumbuh kembang anak. Tumbuh kembang anak adalah proses perubahan fisik dan fungsi tubuh pada anak yang bekerja secara simultan. Pentingnya mengetahui fase tumbuh kembang anak akan mempengaruhi pola asuh orang tua dalam memberikan pengetahuan dan pemahaman kepada anak.

\section{Diskursus Anak}

Dalam Kamus Besar Bahasa Indonesia, istilah anak mengandung makna keturunan kedua. ${ }^{2}$ Yaitu seseorang yang dilahirkan dari orang tua. Dalam Undang-undang No. 23 Tahun 2002 tentang perlindungan anak, dijelaskan bahwa anak adalah amanah dan karuni Tuhan Yang Maha Esa, yang dalam dirinya melekat harkat dan martabat sebagai manusia seutuhnya. ${ }^{3}$ Menurut Abdul Razaq Husain menjelaskan bahwa anak merupakan amanah bagi orang tua yang harus dijaga dengan baik dan hak anak merupakan kewajiban bagi orang tua yang harus

\footnotetext{
${ }^{1}$ Direktorat Tenaga Teknis. Pertumbuhan dan Perkembangan Anak Usia Dini, 0 - 6 Tahun, (Jakarta: PT Grasindo, 2003), hal.1

${ }^{2}$ https://kbbi.kemdikbud.go.id/entri/anak, diakses pada tanggal 05 Desember 2018 pukul. 02.58.

${ }_{3}^{3}$ M. Nasir Djamil, Anak Bukan Untuk Dihukum, (Jakarta: Sinar Grafika, 2013), hal. 8.
} 
dilaksanakan sebagaimana yang telah digariskan dalam ajaran Islam yang berasal Alquran dan hadis. $^{4}$

Dari pengertian di atas anak merupakan harapan orang tua yang keberadaannya selalu dinantikan. Selain itu anak merupakan amanah bagi orang tua, yang memiliki hak terpenuhi kebutuhan anak berdasarkan kemampuan orang tua, Sedangkan kewajiban anak adalah berbakti kepada orang tua. Anak didefinisikan sebagai seseorang yang berusia muda dan dalam rentang usia anak merupakan usia labil, maka keberadaannya mudah untuk dipengaruhi dan dikendalikan.

Pendapat tersebut senada dengan R.A. Kosnan yang menjelaskan anak adalah manusia muda dan berusia muda dalam jiwa dan perjalanan hidup, mudah terpengaruh untuk keadaan sekitarnya. ${ }^{5}$ Dari pengertian ini dapat dijelaskan bahwa anak-anak adalah bagian dari manusia yang kehidupannya masih dalam pengaruh orang tua atau orang yang lebih tua, untuk itu agar anak-anak dapat tumbuh dengan baik, setiap orang yang berada di sekelilingnya harus memahami pola tumbuh kembang anak berdasarkan tahapan usia perkembangan anak, serta memberikan stimulus untuk mengembangkan aspek fisik, psikis, sosio-emosional, psikomotorik dan seni. Dengan pola asuh dan stimulus yang baik maka akan membentuk kepribadian dan karakter anak yang menjadi bekal untuk masa depannya. Selain pola asuh berdasarkan usia dan memberikan stimulus, hal yang lebih penting adalah memberikan kasih sayang, perhatian dan penghargaan kepada anak sebagai manusia yang memiliki keinginan dan kebebasan untuk melakukan kehidupan. Agar anak dapat tumbuh dan berkembang dengan memiliki kepribadian dan karakter yang siap menjadi generasi masa datang.

Lebih lanjut dikatakan bahwa anak adalah tunas, potensi, dan generasi muda penerus cita-cita perjuangan bangsa, memiliki peran strategis dan mempunyai ciri dan sifat khusus yang menjamin kelangsungan eksistensi bangsa dan negara pada masa depan. Oleh karena itu agar setiap anak kelak mampu memikul tanggung jawab tersebut, maka ia perlu mendapat kesempatan yang seluas-luasnya untuk tumbuh dan berkembang secara optimal, baik fisik, mental maupun sosial, dan berakhlak mulia, perlu dilakukan upaya perlindungan serta untuk mewujudkan kesejahteraan anak dengan memberikan jaminan terhadap pemenuhan hakhaknya serta adanya perlakuan tanpa diskriminasi. ${ }^{6}$

${ }^{4}$ Abdul Razaq Husain, Hak-hak Anak dalam Islam diterjemahkan oleh Azwir Butan dengan judul buku Islam wa Tiflu, (Jakarta: Fika Hati Aniska, 1992), hal. 49.

${ }^{5}$ R.A. Koesnan, Susunan Pidana dalam Negara Sosialis Indonesia, (Bandung: Sumur, 2005), hal. 113

${ }^{6}$ M. Nasir Djamil, Anak Bukan Untuk Dihukum, ..., hal. 8. 
Pentingnya memberikan perhatian dan kesejahteraan kepada anak-anak baik yang berkaitan dengan fisik, sosial emosional, kognitif dan pendidikan akhlak (karakter) dapat mendorong anak menjadi manusia yang dewasa yang siap berkiprah dan bersinergi dalam dunia kerja, kehidupan dalam masyarakat dan kehidupan berbangsa dan bernegara.

Terdapat perbedaan pendapat dalam menentukan batasan usia anak. Perserikatan BangsaBangsa (PBB) dalam Convention on the Right of Child (CRC) menjelaskan anak adalah setiap manusia di bawah umur 18 tahun. Dalam Undang-undang Nomor 35 Tahun 2014 menyebutkan bahwa anak adalah seseorang yang belum berusia 18 (delapan belas) tahun, termasuk anak yang masih dalam kandungan. Dalam undang-undang perlindungan anak tersebut dijelaskan batasan tidak hanya batasan maksimal namun ada batasan minimal, yaitu dalam kandungan.

Batasan usia minimal anak adalah sejak dalam kandungan dan berakhir pada usia 18 tahun. Pada usia ini berbagai perubahan perkembangan psikis dan pertumbuhan fisik banyak terjadi. Maka tugas orang tua mendidik dan mendampingi anak agar tumbuh dan berkembang sesuai dengan usianya. Setiap orang tua menghendaki yang terbaik untuk anak-anaknya. Untuk itu orang tua berupaya untuk kerja keras menyiapkan kebutuhan anak-anaknya, mulai dari kebutuhan sandang, pangan, papan, pendidikan terbaik, dan membekali dengan berbagai keterampilan.

Dalam pandangan agama Islam, anak adalah amanah dari Allah Swt. Setiap orang tua yang dikaruniai anak bertanggung jawab atas kehidupan anak baik di dunia maupun akhirat. Selain menjadi amanah orang tua mendapatkan kebahagiaan, karena anak diumpamakan sebagai perhiasan sehingga keberadaannya sangat dinanti dan ditempatkan spesial di hati orang tua. Anak juga menjadi penyejuk hati orang tua, penghilang lelah dikala capek bekerja.

Dalam konteks negara, anak merupakan generasi penerus yang memiliki hak untuk mendapatkan pendidikan dalam program wajib belajar sembilan tahun, sehingga keberadaannya kelak dapat menentukan arah bangsa dan negara. Selain itu negara mengatur berbagai ketentuan usia anak baik yang berkaitan dengan perkawinan, hukum, dan bekerja. Aturan tersebut dibuat berdasarkan tahapan perkembangan anak baik tahapan perkembangan fisik maupun psikis, hal ini bertujuan untuk membantu kesiapan anak dan kedewasaan anak.

\section{Fase Tumbuh Kembang Anak}

Pertumbuhan dan perkembangan (tumbuh kembang) adalah dua hal yang berbeda, akan tetapi memiliki keterikatan. Pertumbuhan adalah berkaitan dengan fisik sedangkan perkembangan berkaitan dengan psikis. Setiap manusia baik anak-anak maupun dewasa mengalami proses pertumbuhan dan perkembangan. 
Pertumbuhan adalah perubahan secara fisiologis sebagai hasil dari proses pematangan fungsifungsi fisik yang berlangsung secara normal pada anak yang sehat dalam passage (peredaran waktu tertentu). ${ }^{7}$ Sedangkan perkembangan anak adalah proses transmisi dari konstitusi fisik (keadaan jasmaniah) yang turun menurun (herediter) dalam bentuk proses aktif secara berkesinambungan. ${ }^{8}$

Perkembangan memiliki arti perubahan secara kualitatif pada ranah jasmani dan rohani manusia yang saling berkesinambungan menuju ke arah yang lebih baik atau ke arah yang sempurna. Yang dimaksud perubahan fisik pada perkembangan manusia ialah mengacu pada optimalisasi fungsi-fungsi organ jasmaniah manusia, bukan pada pertumbuhan jasmaniah itu sendiri. Sehingga dari sini dapat terlihat bahwa pertumbuhan dan perkembangan adalah sesuatu yang berbeda tetapi saling berkesinambungan atau berhubungan. ${ }^{9}$

Pertumbuhan mempunyai ciri-ciri khusus, yaitu perubahan ukuran, perubahan proporsi, hilangnya ciri-ciri lama, serta munculnya ciri-ciri baru. Keunikan pertumbuhan adalah mempunyai kecepatan yang berbeda-beda di setiap kelompok umur dan masing-masing organ juga mempunyai pola pertumbuhan yang berbeda. Terdapat 3 periode pertumbuhan cepat, yaitu masa janin, masa bayi $0-1$ tahun, dan masa pubertas.

Untuk lebih lengkap menjelaskan mengenai pertumbuhan dan perkembangan, persamaan dan perbedaan keduanya, berikut disajikan dalam bentuk tabel:

Tabel. 1 Perbedaan Istilah Pertumbuhan dan Perkembangan ${ }^{10}$

\begin{tabular}{|l|l|l|}
\hline & Pertumbuhan & Perkembangan \\
\hline Persamaan & $\begin{array}{l}\text { Perubahan progresif (masa } \\
\text { prenatal, bayi, anak, remaja dan } \\
\text { dewasa muda), akan tetapi pada } \\
\text { tahapan dewasa madya dan akhir } \\
\text { terjadi perubahan regresif. }\end{array}$ & $\begin{array}{l}\text { Cenderung mengalami perubahan } \\
\text { progresif secara stabil }\end{array}$ \\
\hline Perbedaan & $\begin{array}{l}\text { Bersifat Kuantitatif } \\
\text { Dapat diukur secara pasti, eksak } \\
\text { dan akurat }\end{array}$ & $\begin{array}{l}\text { Perubahan dari potensi menjadi } \\
\text { kemampuan }\end{array}$ \\
\hline
\end{tabular}
hal. 18 .

${ }^{7}$ Kartini Kartono, Psikologi Anak (Psikologi Perkembangan), (Bandung: Mandar Maju, 1995), Cet-5,

${ }^{8}$ Kartini Kartono, Psikologi Anak (Psikologi Perkembangan), ... hal. 18.

${ }^{9}$ Muhibbin Syah, Psikologi Pendidikan dengan Pendekatan Baru Edisi Revisi, (Bandung: PT Remaja Rosdakarya, 2004), hal 42.

${ }^{10}$ Agus Dariyo, Psikologi Perkembangan Anak Tiga Tahun Pertama, (Bandung: PT. Refika Aditama, 2011), hal. 36 . 


\begin{tabular}{|l|l|l|}
\hline & $\begin{array}{l}\text { Ditandai dengan kematangan organ } \\
\text { fisik, kompleksitas sistem jaringan } \\
\text { otot maupun sistem syaraf. }\end{array}$ & $\begin{array}{l}\text { Ditandai dengan kesiapan fisik } \\
\text { untuk melakukan sesuatu dan } \\
\text { memiliki pengalaman. }\end{array}$ \\
\hline $\begin{array}{l}\text { Kematangan fisik dan sistem syaraf } \\
\text { akan menyebabkan perkembangan } \\
\text { perilaku motorik kasar dan halus }\end{array}$ & $\begin{array}{l}\text { Pengalaman awal dapat ditransfer } \\
\text { pada pengalaman yang sama } \\
\text { maupun kegiatan lainnya. }\end{array}$ \\
\hline
\end{tabular}

Proses perkembangan terjadi secara simultan dengan pertumbuhan, sehingga setiap pertumbuhan disertai dengan perubahan fungsi. Perkembangan merupakan hasil interaksi kematangan susunan saraf pusat dengan organ yang dipengaruhinya. Perkembangan fase awal meliputi beberapa aspek kemampuan fungsional, yaitu kognitif, motorik, emosi, sosial, dan bahasa. Perkembangan pada fase awal ini akan menentukan perkembangan fase selanjutnya. Kekurangan pada salah satu aspek perkembangan dapat mempengaruhi aspek lainnya.

Salah satu teori yang di gunakan dalam tumbuh kembang anak adalah teori kognisi dan moral Jean Piaget. ${ }^{11}$ Istilah kognisi (kognitif) berasal dari kata cognition berarti mengetahui. Dalam arti yang luas cognitive (kognisi) ialah perolehan, penataan, dan penggunaan pengetahuan. Dalam perkembangan selanjutnya, istilah kognitif menjadi popular sebagai salah satu domain atau ranah psikologis manusia yang mencakup setiap perilaku mental yang berhubungan dengan pemahaman, pertimbangan, pengolahan informasi, pemecahan masalah, kesengajaan, dan keyakinan. Ranah kejiwaan yang berpusat di otak ini juga berhubungan dengan konasi (kehendak) dan afeksi (perasaan) yang bertalian dengan ranah rasa. ${ }^{12}$

Dalam teori kognisi ini tidak hanya berkaitan dengan kemampuan pemahaman seseorang saja akan tetapi keterlibatan rasa, perasaan dan kehendak menjadi bagian yang tidak dapat dipisahkan. Teori ini sejalan dengan taksonomi Benjamin S. Blom dalam ranah pendidikan, di mana tujuan pendidikan harus mencakup wilayah kognitif, afektif dan psikomotorik. ${ }^{13}$

\footnotetext{
${ }^{11}$ Jean Piaget lahir pada tanggal 9 Agustus 1898 di Neuchatel, Swiss. adalah seorang filsuf, ilmuwan, dan psikolog perkembangan Swiss, yang terkenal karena hasil penelitiannya tentang anak-anak dan teori perkembangan kognitifnya.

${ }^{12}$ Muhibbin, Syah. Psikologi Belajar, Jakarta: Rajawali Pers, 2012, ..hal. 22

13 Ranah kognitif adalah ranah pembelajaran yang menggunakan aktivitas otak atau berpikir yang berorientasi pada pengembangan intelektual yang di dalamnya mengandung aspek pengetahuan, pemahaman, penerapan, analisis dan sintetis. Sedangkan ranah psikomotorik adalah kegiatan pembelajaran yang berorientasi pada skill atau kemampuan. Sedangkan ranah afektif adalah proses pembelajaran yang berorientasi pada sikap dan nilai, seperti perasaan sikap, emosi, dan nilai.
} 
Menurut Piaget terjadinya perkembangan terhadap manusia melalui proses adaptasi, asimilasi, akomodasi dan ekuilibrasi ${ }^{14}$ Adaptasi adalah proses menyesuaikan skema sebagai tanggapan atas lingkungan melalui asimilasi dan akomodasi. Sedangkan asimilasi adalah memahami pengalaman baru berdasarkan skema yang ada. Adapun akomodasi adalah skema yang ada agar sesuai dengan situasi yang baru. Ekuilibrasi adalah proses memulihkan keseimbangan antara pemahaman sekarang dan pengalaman baru. ${ }^{15}$

Teori perkembangan kognisi ini menganggap proses sebagai bagian yang penting dengan memusatkan pada perhatian berpikir anak, perhatian terhadap proses mental anak, memperhatikan pengalaman-pengalaman belajar sehingga proses lebih diutamakan daripada hasil. Selain itu anak distimulasi untuk tetap aktif, memiliki inisiatif dalam melakukan kehidupan. Hal yang tidak bisa diabaikan adalah memahamkan kepada anak akan adanya perbedaan setiap orang, sehingga dapat menghargai perbedaan dan keragaman kepada setiap orang.

Teori kognisi dalam kajian psikologi menjelaskan belajar merupakan peristiwa mental. Meskipun yang bekerja adalah perilaku fisik, di mana keterlibatan mata dan mulut seseorang dalam membaca, akan tetapi menggerakkan mulut, mata dan pena dalam menulis dan membaca merupakan dorongan mental yang diatur oleh otak. ${ }^{16}$

Dari proses perkembangan manusia dalam merespons kehidupan yang telah dijelaskan di atas, manusia adalah makhluk yang memiliki rangkaian proses. Hal tersebut merupakan potensi dasar yang dimiliki. Untuk itu Piaget membuat tahapan perkembangan anak yang disebut dengan fase perkembangan kognisi.

Teori Piaget sering kali disebut konstruktivisme personal karena lebih menekankan keaktifan pribadi seseorang dalam mengonstruksikan pengetahuan. Teori konstruktivisme menjelaskan bahwa pengetahuan seseorang adalah bentukan (konstruksi) orang itu sendiri. Pengetahuan seseorang tentang suatu benda, bukanlah tiruan benda, melainkan konstruksi pemikiran seseorang akan benda tersebut. Tanpa keaktifan seseorang dalam mencerna dan membentuknya, seseorang tidak akan mempunyai pengetahuan. Oleh karena itu Piaget

\footnotetext{
${ }^{14}$ Robert E Slavin, Psikologi Pendidikan Teori dan Praktek, diterjemahkan oleh Marianto Samosir dari judul Educational Psychology: Theory and Practice, (Jakarta: PT. Indeks Permata Puri, 2011), hal. 43.

${ }^{15}$ Skema adalah pola mental yang menuntun perilaku, dimana setiap anak yang dilahirkan membawa kecenderungan dapat berinteraksi dengan lingkungan. Robert E Slavin, Psikologi Pendidikan Teori dan Praktek, ... hal. 42-43.

${ }^{16}$ Mahmud, Psikologi Pendidikan, (Bandung: Pustaka Setia, 2010), hal. 83.
} 
menyatakan secara ekstrem bahwa pengetahuan tidak dapat ditransfer dari otak guru yang dianggap tahu bila murid tidak mengolah dan membentuknya sendiri. ${ }^{17}$

Dalam teori Piaget ini keterlibatan anak sangat mempengaruhi kemampuan kognisinya. Untuk itu teori ini menekankan pentingnya kebebasan anak dalam melakukan kegiatan untuk menciptakan kreativitas dan mengembangkan pemahaman dan pengetahuan yang sudah ada untuk dikembangkan lebih inovatif dalam proses pembelajar.

Piaget membagi tahapan perkembangan kognisi anak melalui empat tahapan, yaitu tahap sensorimotor (usia lahir-2 tahun) pada tahapan ini pembentukan konsep "keajegan objek" dan kemajuan berkembang dari perilaku refleks ke perilaku yang diarahkan tujuan. Tahap praoperasi (usia 2-7 tahun), pada tahap ini tahapan mampu menggunakan simbol, dan secara psikis bersifat egosentris. Tahap Operasi Konkret (usia 7-11 tahun) mulai berpikir logis dan dapat memecahkan masalah akademis seta dapat membentuk kemampuan baru meliputi pengoperasian yang dapat dibalik. Tahap Operasi Formal (usia 11-dewasa) Berpikir secara abstrak dan simbolik serta dapat memecahkan masalah secara eksperimentasi sistematik. ${ }^{18}$ Berikut ini akan dijelaskan tahapan perkembangan kognisi menurut Piaget dalam bentuk tabel 2 berikut:

Tabel 2. Tahap Perkembangan Kognisi Menurut Piaget

\begin{tabular}{|c|l|l|l|}
\hline Tahap & $\begin{array}{c}\text { Perkiraan } \\
\text { Usia }\end{array}$ & & \multicolumn{1}{|c|}{ Keterangan } \\
\hline Sensorimotor & $0-2$ tahun & $\begin{array}{l}\text { pembentukan konsep } \\
\text { "keajegan objek" dan } \\
\text { kemajuan berkembang dari } \\
\text { perilakua refleks ke perilaku } \\
\text { yang diarahkan tujuan }\end{array}$ & $\begin{array}{l}\text { Kemampuan anak untuk } \\
\text { berinteraksi dengan } \\
\text { lingkungan. Berawal dari } \\
\text { perilaku bawaan (gerakan } \\
\text { refleks) anak (bayi) akan } \\
\text { melakukan perilaku yang } \\
\text { lebih menarik. Tahap } \\
\text { sensori ini diakhiri dengan } \\
\text { upaya anak dalam }\end{array}$ \\
\hline
\end{tabular}

17 Tri Yuni Hendrowati, Pembentukan Pengetahuan Lingkaran Melalui Pembelajaran Asimilasi Dan Akomodasi Teori Konstruktivisme Piaget, Jurnal e-DuMath Program Studi Pendidikan Matematika, STKIP Muhammadiyah Pringsewu Lampung Volume 1 No. 1, Januari 2015 hal. 1-16

${ }^{18}$ Robert E Slavin, Psikologi Pendidikan Teori dan Praktek, ... hal. 45. 


\begin{tabular}{|c|c|c|c|}
\hline & & & $\begin{array}{l}\text { memecahkan masalah } \\
\text { secara dasar. }\end{array}$ \\
\hline Praoperasi & 2-7 tahun & $\begin{array}{l}\text { Perkembangan kemampuan } \\
\text { menggunakan simbol untuk } \\
\text { melambangkan objek di } \\
\text { dunia. Pemikirannya bersifat } \\
\text { egosentris dan terpusat }\end{array}$ & $\begin{array}{l}\text { Dalam tahap ini } \\
\text { kemampuan bahasa } \\
\text { berkembang pesat. Anak } \\
\text { belajar melambangkan } \\
\text { sesuatu ke dalam pikiran. } \\
\text { Anak beranggapan bahwa } \\
\text { sifat suatu objek akan tetap } \\
\text { walaupun terjadi perubahan } \\
\text { sifat (konservasi), dan anak } \\
\text { di usia ini memberikan } \\
\text { perhatian hanya pada satu } \\
\text { objek saja, } \\
\text { kecenderungannya bersifat } \\
\text { egosentris }\end{array}$ \\
\hline $\begin{array}{l}\text { Operasi } \\
\text { Konkret }\end{array}$ & 7-11 tahun & $\begin{array}{l}\text { Perbaikan kemampuan } \\
\text { berpikir logis. Kemampuan } \\
\text { baru meliputi penggunaan } \\
\text { pengoperasian yang dapat } \\
\text { dibalik. Pemikiran tidak } \\
\text { terpusat, dan pemecahan } \\
\text { masalah kurang dibatasi oleh } \\
\text { egosentrisme. Pemikiran } \\
\text { abstrak tidak mungkin }\end{array}$ & $\begin{array}{l}\text { Pada tahap ini anak } \\
\text { mengembangkan } \\
\text { kemampuan untuk bernalar } \\
\text { logis dan memahami } \\
\text { konservasi. dapat } \\
\text { menyusun objek dan } \\
\text { mengurutkan berdasarkan } \\
\text { satu aspek, seperti ukuran } \\
\text { besar, berat dan volume. }\end{array}$ \\
\hline $\begin{array}{l}\text { Operasi } \\
\text { Formal }\end{array}$ & 11-dewasa & $\begin{array}{l}\text { Pemikiran abstrak dan } \\
\text { semata-mata simbolik } \\
\text { dimungkinkan. Masalah } \\
\text { dapat dipecahkan melalui } \\
\text { penggunaan eksperimentasi } \\
\text { sistematik }\end{array}$ & $\begin{array}{l}\text { Pada tahap ini anak sudah } \\
\text { dapat berpikir abstrak dan } \\
\text { dapat membandingkan } \\
\text { objek-objek dalam pikiran } \\
\text { serta dapat berpikir tentang } \\
\text { objek dan hubungannya } \\
\text { pada tingkat yang lebih } \\
\text { rendah. }\end{array}$ \\
\hline
\end{tabular}


Selain teori kognisi, Piaget juga mengembangkan teori moral. Teori ini bertujuan agar setiap manusia dalam kehidupan sosial mampu berkomunikasi, menempatkan diri dan mengikuti aturan yang ditetapkan. Ada korelasi antara kognisi dan moral di mana keduanya akan saling beriringan karena tujuan akhir dalam proses perkembangan adalah kematangan moral.

Piaget dalam Slavin menjelaskan bahwa perkembangan moral berlangsung dalam tahap-tahap yang dapat diprediksi, dari tipe egosentris menuju tipe perkembangan moral sistem keadilan berdasarkan hubungan kerja sama dan timbal balik. Piaget membagi perkembangan moral ke dalam dua bagian yaitu Moralitas Heteronom dan Moralitas Otonom. ${ }^{19}$

Moralitas Heteronom atau juga disebut realisme moral, yaitu tahapan moral yang diperuntukkan untuk-anak-anak. Heteronom mengandung arti tunduk pada aturan. Pada fase ini, anak-anak akan mengikuti apa yang dilihat, apa yang didengar dan apa yang diperintahkan orang dewasa (orang tua). Sampai usia 12 tahun anak-anak akan mudah untuk dikendalikan dan diberikan aturan. Sedangkan Moralitas Otonom atau disebut juga moralitas kerja sama di mana anak-anak sudah mulai bisa bekerja sama dan mempunyai teman yang dapat diajak berinteraksi, sehingga keterikatan dengan orang tua akan sedikit demi sedikit teratasi. Dalam memberikan aturan hendaknya di jenjang ini orang tua atau pendidik berkomunikasi dan menyetujui aturan secara bersama. Berikut tabel tahapan perkembangan moral Piaget: ${ }^{20}$

Tabel 3. Tahap Perkembangan Moral Piaget

\begin{tabular}{|l|l|}
\hline Moralitas Heteronom (Anak Kecil) & Moralitas Otonom (Anak Besar) \\
\hline $\begin{array}{l}\text { Berdasarkan pada hubungan paksaan (doktrin) } \\
\text { orang tua terhadap anak-anak yang berkaitan } \\
\text { dengan aturan. }\end{array}$ & $\begin{array}{l}\text { Berdasarkan pada hubungan kerja sama dan } \\
\text { pengakuan bersama terhadap kesetaraan di } \\
\text { antara individu yang otonom. }\end{array}$ \\
\hline $\begin{array}{l}\text { Prinsip aturan dengan menggunakan realisme } \\
\text { moral, di mana aturan dipandang sebagai }\end{array}$ & $\begin{array}{l}\text { Prinsip aturan menggunakan moral rasional, } \\
\text { di mana aturan berdasarkan kesepakatan }\end{array}$ \\
\hline
\end{tabular}

19 Untuk memahami penalaran moral, Piaget banyak melakukan terhadap anak-anak. Pengamatan pertama menemukan bahwa anak-anak sebelum usia 6 tahun bermain aturan berdasarkan kemauan dan egosentris sendiri. Pada usia ini anak belum bisa kerjasama karena nalar moralnya belum berjalan. Robert E Slavin, Psikologi Pendidikan Teori dan Praktek, ..., hal. 68-69.

20 Sumber dari Social and Personality Development dicetak ulang dengan izin Wodsworth, divisi Thomson Leraning dalam Robert E Slavin, Psikologi Pendidikan Teori dan Praktek, ..., hal. 68. 


\begin{tabular}{|l|l|}
\hline $\begin{array}{l}\text { ketentuan yang tidak fleksibel, asal dan } \\
\text { wewenangnya dari luar, tidak terbuka } \\
\text { negosiasi. }\end{array}$ & $\begin{array}{l}\text { bersama, terbuka untuk negosiasi, } \\
\text { mengedepankan asas kerja sama dan saling } \\
\text { menghargai. }\end{array}$ \\
\hline $\begin{array}{l}\text { Keadilan berdasarkan keputusan orang dewasa, } \\
\text { tindakan semena-mena dianggap adil. } \\
\text { Kejahatan dinilai berdasarkan bentuk obyektif } \\
\text { dan konsekuensi tindakan. }\end{array}$ & $\begin{array}{l}\text { Keadilan diartikan sebagai perlakuan setara } \\
\text { atau kesediaan mempertimbangkan } \\
\text { kebutuhan individu, dalam hukuman } \\
\text { berdasarkan kepantasan atas pelanggaran }\end{array}$ \\
\hline $\begin{array}{l}\text { Keadilan dilihat sebagai sesuatu yang melekat, } \\
\text { sedangkan kejahatan dipandang sebagai } \\
\text { konsekuensi otomatis pelanggaran. }\end{array}$ & $\begin{array}{l}\text { Hukuman dipandang sebagai sesuatu yang } \\
\text { dipengaruhi oleh maksud manusia. }\end{array}$ \\
\hline
\end{tabular}

Dari dua teori yang dikembangkan Piaget tersebut, menjadi fondasi awal untuk orang tua dan pendidik dalam proses tumbuh kembang anak. Dengan begitu orang tua dan pendidik dapat memberikan tahapan pendidikan dan pemahaman yang disesuaikan dengan tumbuh kembang anak. Proses tumbuh kembang yang terjadi pada anak juga perlu distimulus dengan baik, sehingga akan membentuk karakter anak menjadi baik sesuai usia perkembangannya.

\section{Diskursus Karakter}

Dari segi bahasa, istilah karakter berasal dari dari bahasa Latin "Kharakter”, "Kharassein”, "Kharax", dalam ${ }^{21}$ bahasa Inggris "Character" bahasa Yunani Charassein yang berarti membuat tajam. ${ }^{22}$ Sedangkan Karen E Bohlin mendefinisikan karakter sebagai tanda khusus atau pola perilaku seseorang yang sesuai dengan kaidah moral. ${ }^{23}$ Menurut Kamus Poerwadarminta, istilah karakter diartikan sebagai tabiat, watak, sifat-sifat kejiwaan, akhlak atau budi pekerti yang membedakan seseorang dengan yang lain.

Menurut Kamus Besar Bahasa Indonesia, kata karakter mengandung arti sifat-sifat kejiwaan, akhlak, tabiat, watak, atau budi pekerti yang membedakan seseorang dari yang lain. ${ }^{24}$ Sedangkan karakter menurut Pusat Bahasa Depdiknas bermakna bawaan hati, jiwa kepribadian, budi pekerti, perilaku, personalitas, sifat, tabiat, temperamen watak. ${ }^{25}$

21 Abdul Madjid dan Dian Andayani, Pendidikan Karakter Perspektif Islam, (Bandung: Remaja Rosdakarya, 2017), cet-4, hal. 11.

${ }^{22}$ Abdul Madjid dan Dian Andayani, Pendidikan Karakter Perspektif Islam, ... hal. 11.

${ }^{23}$ Definisi ini dari kata karakter "charassein" (to engrave) yang berarti mengukir. Membentuk karakter diibaratkan seperti mengukir permukaan besi yang membutuhkan waktu yang lama dan konsisten. Karen E. Bohlin, Deborah Farmer, Kevin Ryan, Building Character in School Resource Guide (San Fransisco: Jossey Bass, 2001), hal. 1

${ }^{24}$ https://kbbi.kemdikbud.go.id/entri/karakter. Diakses Pada tanggal 16 April 2018, pukul. 18.00.

25 Ulil Amri Syafri, Pendidikan Karakter Berbasis Al-Qur'an, (Jakarta: Rajagrafindo, 2014), cet-2, hal. 7. 
Dalam kamus filsafat karakter dapat didefinisikan sebagai nama dari jumlah seluruh ciri pribadi yang mencakup perilaku, kebiasaan, kesukaan, ketidaksukaan, kemampuan, kecenderungan, potensi, nilai-nilai, dan pola-pola pemikiran. ${ }^{26}$ Menurut Griek yang dikutip Zubaedi dalam buku Samsul Kurniawan menjelaskan karakter sebagai paduan tabiat manusia yang bersifat tetap sehingga menjadi tanda yang khusus untuk membedakan orang yang satu dengan yang lain. ${ }^{27}$ Dari definisi di atas, dapat dijelaskan bahwa karakter merupakan pola pikir, perbuatan dan tingkah laku yang tetap yang mengakar dalam diri seseorang yang menjadi ciri khas antara manusia yang satu dengan yang lainnya, yang terbentuk melalui pembiasaan yang berlangsung terus menerus.

Karakter adalah sifat pribadi yang relatif pada diri individu yang menjadi landasan bagi penampilan perilaku dalam standar nilai dan norma yang tinggi. ${ }^{28}$ Definisi ini mengandung kata kunci yaitu relatif stabil, landasan, penampilan perilaku dan standar nilai atau norma. Prayitno dan Belferik Manullang menjelaskan kata kunci relatif stabil sebagai suatu kondisi jika sudah terbentuk akan sulit diubah, sedangkan landasan adalah kekuatan yang pengaruhnya sangat besar dan menyeluruh terhadap hal-hal yang berkaitan dengan kekuatan. Adapun penampilan perilaku adalah aktifitas individua tau kelompok dalam bidang tertentu dan wilayah dimana berada. Sedangkan standar nilai atau norma adalah kondisi yang mengacu pada kaidah-kaidah agama, ilmu dan teknologi, hukum, adat, dan kebiasaan yang tercermin dalam perilaku sehari-hari.

Ibnu Miskawaih mendefinisikan karakter sebagai suatu keadaan jiwa yang bersifat alami yang menyebabkan tindakan secara spontan tanpa dipertimbangkan secara mendalam oleh seseorang dalam melakukan aktivitas. ${ }^{29}$ Miskawaih menggambarkan karakter dalam dua jenis. Pertama, karakter bersifat alami yang berasal dari watak seseorang, seperti seseorang yang mudah marah meskipun hal-hal yang sepele, mudah tertawa karena hal yang sepele, atau seseorang mudah takut karena mendengar berita-berita yang kurang mengenakkan. Selain bersifat alami, yang kedua, karakter tumbuh dan tercipta melalui kebiasaan dan latihan yang terus menerus karena

${ }^{26}$ Pengertian di atas dapat diasumsikan sebagai kerangka kepribadian yang relative mapan yang memungkinkan ciri-ciri dapat mewujudkan diri. Lorens Bagus, Kamus Filsafat, (Jakarta: Gramedia, 2005), hal. 392.

27 Untuk membentuk karakter tersebut Zubaedi menjelaskan perlu adanya sinergitas antara sikap (attitudes), perilaku (behavior), motivasi (motivation), dan keterampilan (skill). Syamsul Kurniawan, Pendidikan Karakter: Konsepsi dan Implementasinya Secara Terpadu di Lingkungan Keluarga, Sekola h, Perguruan Tinggi dan Masyarakat, (Yogyakarta: Ar-Ruzz Media), 2013, hal. 28-29.

28 Prayitno dan Belferik Manullang, Pendidikan Karakter dalam Pembangunan Bangsa, (Jakarta: Kompas Gramedia, 2011), hal. 47.

29 Ibn Miskawaih, Menuju Kesempurnaan Aklak: Buku DarasPertama tentang Filsafat Etika, diterjemahkan oleh Helmi Hidayat dari judul Tahdzibal-Akhlak, (Jakarta: Mizan, 1998), hal. 56-57. 
kesadaran secara personal atau karena lingkungan baik keluarga, sekolah dan masyarakat yang memberikan stimulus untuk melakukan karakter yang baik, sebagai contoh seorang anak yang dicontohkan oleh orang tuanya untuk selalu meminta maaf ketika melakukan kesalahan, maka dengan latihan dan pembiasaan yang terus menerus akan membentuk karakter pemaaf.

Sedangkan al-Ghazali mendefinisikan karakter (akhlak) adalah kondisi atau keadaan yang menetap di dalam jiwa manusia, di mana semua perilaku bersumber darinya dengan penuh kemudahan tanpa memerlukan proses berpikir dan merenung. Jika kondisi atau keadaan jiwanya menjadi sumber perbuatan-perbuatan yang baik dan terpuji, baik itu secara akal dan syariat, maka kondisi itu disebut sebagai akhlak yang baik, dan jika yang bersumber darinya adalah perbuatan-perbuatan yang buruk, maka kondisi itu disebut sebagai akhlak yang buruk. ${ }^{30}$ Selain tokoh muslim, definisi karakter juga disampaikan oleh filosof Yunani ${ }^{31}$ yaitu Aristoeles yang dikutip oleh Thomas Lickona menjelaskan bahwa tindakan yang benar dalam kehidupan seseorang yang dilakukan terhadap diri sendiri yang erat kaitannya dengan orang lain dalam hubungan keseharian dengan menitikberatkan pengendalian diri dan empati. Sedangkan Michael Novak seorang filosof kontemporer menjelaskan karakter terbentuk dari kumpulan yang diidentifikasi oleh tradisi religius, sastra, kaum bijaksana, dan kumpulan orang berakal sehat yang ada dalam sejarah.

Dari dua definisi karakter yang disampaikan oleh para filosof tersebut, Thomas Lickona memberikan penjelasan bahwa karakter terbentuk dari pengetahuan moral, perasaan moral dan perilaku moral yang semuanya harus berjalan beriringan dan saling melengkapi, sehingga terciptalah karakter yang baik dengan mengetahui hal yang baik, menginginkan hal yang baik, dan melakukan hal yang baik yang pada akhirnya menjadi kebiasaan dalam berpikir, kebiasaan dalam hati dan kebiasaan dalam bertindak. Lebih jauh Thomas Lickona menjelaskan karakter adalah objektivitas yang baik atas kualitas manusia baik secara individu maupun secara sosial, sehingga dengan diperkuat oleh agama dan budaya, karakter yang tertanam dalam diri manusia akan tetap kuat dan melekat. ${ }^{32}$

Ada diskursus karakter yang cukup menarik yang disampaikan oleh Muchlas Samani dan Hariyanto di mana karakter dipengaruhi oleh hereditas. Perilaku seorang anak sering tidak jauh dari perilaku orang tua. Untuk itu karakter dapat didefinisikan sebagai nilai dasar yang

${ }^{30}$ Abu Hamid Muhammad bin Muhammad al Ghazali, Ihya' Ulumuddin, Juz III, (Beirut: Darul Fikr, 2008), hal. 57.

31 Thomas Lickona, Mendidik untuk Membentuk Karakter diterjemahkan oleh Juma Abdu Wamaungo dari judul Educating for Character, (Jakarta: Bumi Aksara), 2015, hal. 81

32 Thomas Lickona, Persoalan Character, diterjemahkan oleh Juma Abdu Wamaungo dan Jean Antunes Rudolf Zien dari judul Character Matters, (Jakarta: Bumi Aksara, 2012), hal. 15-16. 
membangun pribadi seseorang, terbentuk baik karena pengaruh hereditas, maupun pengaruh lingkungan yang membedakan dengan orang lain yang diwujudkan dalam sikap dan perilaku dalam kehidupan sehari-hari.

\section{Fase Tumbuh Kembang dan Pembentukan Karakter Anak}

Masa anak-anak adalah masa yang pesat dalam proses perkembangan dan pertumbuhan. Pada delapan tahun pertama mengalami pertumbuhan dan perkembangan yang pesat, periode ini disebut golden age. Periode golden age hannya terjadi sekali dalam kehidupan manusia yaitu masa anak- anak. Hal ini berdasarkan hasil penelitian di bidang neurologi yang dilakukan oleh Benyamin S. Bloom, seorang ahli pendidikan dari Universitas Chicago, Amerika Serikat mengemukakan bahwa pertumbuhan sel jaringan otak pada anak usia 0-4 tahun mencapai 50\%, hingga usia 8 tahun mencapai $80 \% .{ }^{33}$ Pesatnya perkembangan otak tersebut bersamaan dengan pertumbuhan fisik anak. Untuk itu orang tua harus memberikan stimulasi agar anak dapat tumbuh dan berkembang dengan optimal.

Saat lahir, otak anak sudah mempunyai sel syaraf yang jumlahnya mencapai milyaran, namun jumlah itu banyak yang hilang setelah dilahirkan. Ketika otak mendapatkan suatu stimulus yang baru, maka otak akan mempelajari sesuatu yang baru. Stimulus tersebut akan menyebabkan sel syaraf membentuk sebuah koneksi baru untuk menyimpan informasi. Sel-sel yang terpakai untuk menyimpan informasi tersebut akan mengembang, juga dapat menghasilkan hormon-hormon yang diperlukan dalam perkembangan anak. sedangkan yang tidak atau jarang tersetimulasi akan punah. ${ }^{34}$

Stimulasi yang terus-menerus diberikan secara rutin akan memperkuat hubungan antar syaraf yang telah terbentuk sehingga secara otomatis fungsi otak akan menjadi semakin baik. Stimulasi yang diberikan sejak dini juga akan mempengaruhi perkembangan otak anak. Stimulasi dini yang dimulai sejak usia kehamilan 6 bulan sampai anak usia 3 tahun akan menghasilkan perubahan-perubahan dalam ukuran serta fungsi kimiawi otak. ${ }^{35}$

Pemberian stimulus yang baik selain akan menguatkan jaringan-jaringan dan sel syaraf dalam otak, juga dapat menyimpan semua informasi yang berkaitan dengan perilaku, kecenderungan dan kebiasaan. Semua dapat terpantau dalam otak meskipun prosesnya sangat rumit. Bila

${ }^{33}$ Direktorat Tenaga Teknis. Pertumbuhan dan Perkembangan Anak Usia Dini, 0 - 6 Tahun, (Jakarta: PT Grasindo, 2003), hal.1

34 Atien Nur Chamidah, Pentingnya stimulasi Dini Bagi Tumbuh Kembang Otak Anak, http://staffnew.uny.ac.id/upload/132326899/pengabdian/pentingnya-stimulasi-dini-bagi-tumbuh-kembang-otakanak.pdf, diakses pada hari Minggu, tanggal 03 April 2019, pukul. 17.00.

35 Atien Nur Chamidah, Pentingnya stimulasi Dini Bagi Tumbuh Kembang Otak Anak, http://staffnew.uny.ac.id/upload/132326899/pengabdian/pentingnya-stimulasi-dini-bagi-tumbuh-kembang-otakanak.pdf, diakses pada hari Minggu, tanggal 03 April 2019, pukul. 17.00. 
dianalogikan dengan sebuah komputer, otak manusia menyimpan lebih dari 100 milyar bit informasi. ${ }^{36}$

Bentuk stimulasi dapat diberikan dengan cara mudah dan sederhana. Orang tua dapat memberikan stimulus dengan kasih sayang, penghargaan, pengertian dan perhatian dengan memperhatikan fase usia anak-anak. Selain itu stimulus juga dapat dilakukan melalui pengalaman langsung dengan menggunakan pancaindra, memberikan contoh yang baik kepada anak, karena anak-anak akan belajar dari apa yang dilihat dan yang didengar. Untuk itu figur orang tua menjadi teladan bagi perkembangan anak-anak.

Muchlas Samani dan Hariyanto menjelaskan bahwa karakter dipengaruhi oleh hereditas. Perilaku seorang anak sering tidak jauh dari perilaku orang tua. Untuk itu karakter dapat didefinisikan sebagai nilai dasar yang membangun pribadi seseorang, terbentuk baik karena pengaruh hereditas, maupun pengaruh lingkungan yang membedakan dengan orang lain yang diwujudkan dalam sikap dan perilaku dalam kehidupan sehari-hari.

Pendapat tersebut di atas menggambarkan bahwa orang tua merupakan peletak dasar pembentukan karakter bagi anak-anak. Perilaku dan sikap orang tua di rumah akan menjadi contoh dan panutan anak dalam melakukan kegiatan sehari-hari, begitu juga anak-anak yang sudah sekolah, pendidik (guru) memiliki peran penting terbentuknya karakter peserta didik karena lingkungan sekolah menjadi tempat kedua anak-anak belajar dan bersosialisasi. Karakter harus tertanam dan melekat pada diri masing-masing anak serta mendarah daging dan menjadi kekuatan (otot) dalam diri anak, sehingga ketika anak berbuat dan berperilaku dalam kendali karakter yang ditanamkan.

Lingkungan keluarga (orang tua) menjadi faktor pembentuk pendidikan karakter. Kepercayaan (believe) orang tua akan sesuatu yang diyakini mengenai kebenaran dan kesalahan merupakan faktor pembentuk karakter anak. Jika orang tua meyakini akan sesuatu hal yang dianggap benar, maka hal tersebut akan diturunkan kepada anak.

Believe (kepercayaan) terbentuk bukan terkait persoalan agama atau keyakinan seseorang. Akan tetapi terbentuk karena pengalaman yang berulang-ulang atau pengalaman yang berkesan. ${ }^{37}$ Untuk itu penting kiranya bagi orang tua sebagai pendidik pertama menanamkan kepercayaan positif kepada anak-anak agar tumbuh menjadi pribadi positif dan kuat.

${ }^{36}$ Semuel S. Lusi, SEIP Intelligence: Spiritual, Emotional, Intellectual dan Physique, (Yogyakarta: Kanisius, 2014), hal.67, 70.

${ }^{37}$ Timothy Wibowo, Success Begins with Character, (Surabaya: Pendidikan Karakter, 2018), cet. 3 , hal.171. 
Pentingnya karakter menjadi kekuatan (otot) dalam kepribadian anak-anak juga sebagaimana definisi karakter yang disampaikan Russel Williams sebagaimana dikutip Ratna Megawangi dalam buku Bambang Q-Anees menjelaskan bahwa karakter adalah otot, jika otot tidak dilatih maka akan menjadi lemah dan lembek, ${ }^{38}$ untuk itu perlu latihan yang terus menerus yang pada akhirnya menjadi kebiasaan. Jika karakter diumpamakan otot maka karakter menjadi hal yang penting dalam kehidupan dan merupakan potensi yang ada sejak manusia hadir. Untuk itu pentingnya selalu melakukan hal-hal yang baik agar menjadi kebiasaan dan mendarah daging dalam kehidupan. Seseorang yang memiliki karakter yang baik akan memperlihatkan kepribadian yang baik, karena karakter merupakan bagian yang tidak dapat dipisahkan dari kepribadian seseorang.

\section{Kesimpulan}

Anak-anak adalah bagian dari manusia yang kehidupannya masih dalam pengaruh orang tua atau orang yang lebih tua, untuk itu agar anak-anak dapat tumbuh dengan baik, setiap orang yang berada di sekelilingnya harus memahami pola tumbuh kembang anak berdasarkan tahapan usia perkembangan anak, serta memberikan stimulus untuk mengembangkan aspek fisik, psikis, sosio-emosional, psikomotorik dan seni. Dengan pola asuh dan stimulus yang baik maka akan membentuk kepribadian dan karakter anak yang menjadi bekal untuk masa depannya. Selain pola asuh berdasarkan usia dan memberikan stimulus, hal yang lebih penting adalah memberikan kasih sayang, perhatian dan penghargaan kepada anak sebagai manusia yang memiliki keinginan dan kebebasan untuk melakukan kehidupan. Agar anak dapat tumbuh dan berkembang dengan memiliki kepribadian dan karakter yang siap menjadi generasi masa datang.

38 Bambang Q-Anees dan Adang Hambali, Pendidikan Karakter Berbasis Al-Qurán, (Bandung: Simbiosa Rekatama Media, 2011), cet-3, hal. 99. 
Aas Siti Sholichah

\section{Daftar Pustaka}

Abu Hamid Muhammad bin Muhammad al Ghazali, Ihya' Ulumuddin, Juz III. Beirut: Darul Fikr, 2008.

Agus Dariyo, Psikologi Perkembangan Anak Tiga Tahun Pertama, Bandung: PT. Refika Aditama, 2011.

Anees, Bambang Q- dan Adang Hambali, Pendidikan Karakter Berbasis Al-Qurán, Bandung: Simbiosa Rekatama Media, 2011.

Bagus, Lorens. Kamus Filsafat, Jakarta: Gramedia, 2005.

Bohlin, Karen E. Deborah Farmer, Kevin Ryan, Building Character in School Resource Guide, San Fransisco: Jossey Bass, 2001.

Direktorat Tenaga Teknis. Pertumbuhan dan Perkembangan Anak Usia Dini, 0 - 6 Tahun, Jakarta: PT Grasindo, 2003.

Doni Koesoema, Pendidikan Karakter: Strategi Mendidik Anak di Zaman Modern, Jakarta: PT. Grasindo, 2007.

Djamil, M. Nasir Anak Bukan Untuk Dihukum, Jakarta: Sinar Grafika, 2013.

Husain, Abdul Razaq Hak-hak Anak dalam Islam diterjemahkan oleh Azwir Butan dengan judul buku Islam wa Tiflu, Jakarta: Fika Hati Aniska, 1992.

Kartini Kartono, Psikologi Anak (Psikologi Perkembangan), Bandung: Mandar Maju, 1995.

Kurniawan, Syamsul. Pendidikan Karakter: Konsepsi dan Implementasinya Secara Terpadu di Lingkungan Keluarga, Sekola h, Perguruan Tinggi dan Masyarakat, Yogyakarta: Ar-Ruzz Media, 2013.

Lickona, Thomas Mendidik untuk Membentuk Karakter diterjemahkan oleh Juma Abdu Wamaungo dari judul Educating for Character, Jakarta: Bumi Aksara, 2015.

....... Persoalan Character, diterjemahkan oleh Juma Abdu Wamaungo dan Jean Antunes Rudolf Zien dari judul Character Matters, Jakarta: Bumi Aksara, 2012.

Lusi, Semuel S. SEIP Intelligence: Spiritual, Emotional, Intellectual dan Physique, Yogyakarta: Kanisius, 2014.

Mahmud, Psikologi Pendidikan, Bandung: Pustaka Setia, 2010.

Miskawaih, Ibn Menuju Kesempurnaan Aklak: Buku DarasPertama tentang Filsafat Etika, diterjemahkan oleh Helmi Hidayat dari judul Tahdzibal-Akhlak, Jakarta: Mizan, 1998.

Prayitno. Belferik Manullang, Pendidikan Karakter dalam Pembangunan Bangsa, Jakarta: Kompas Gramedia, 2011.

R.A. Koesnan, Susunan Pidana dalam Negara Sosialis Indonesia, Bandung: Sumur, 2005. 
Slavin, Robert E Psikologi Pendidikan Teori dan Praktek, diterjemahkan oleh Marianto Samosir dari judul Educational Psychology: Theory and Practice, Jakarta: PT. Indeks Permata Puri, 2011.

Syah, Muhibbin Psikologi Pendidikan dengan Pendekatan Baru Edisi Revisi, Bandung: PT Remaja Rosdakarya, 2004, hal 42.

Syafri, Ulil Amri. Pendidikan Karakter Berbasis Al-Qur'an, Jakarta: Rajagrafindo, 2014.

Tri Yuni Hendrowati, Pembentukan Pengetahuan Lingkaran Melalui Pembelajaran Asimilasi Dan Akomodasi Teori Konstruktivisme Piaget, Jurnal e-DuMath Program Studi Pendidikan Matematika, STKIP Muhammadiyah Pringsewu Lampung Volume 1 No. 1, Januari 2015.

Timothy Wibowo, Success Begins with Character, Surabaya: Pendidikan Karakter, 2018. Atien Nur Chamidah, Pentingnya stimulasi Dini Bagi Tumbuh Kembang Otak Anak, http://staffnew.uny.ac.id/upload/132326899/pengabdian/pentingnya-stimulasi-dini-bagitumbuh-kembang-otak-anak.pdf https://kbbi.kemdikbud.go.id/entri/anak, diakses pada tanggal 05 Desember 2018. https://kbbi.kemdikbud.go.id/entri/karakter 